\title{
National emergency risk assessments: comparative study of Estonia and the UK
}

\author{
A. Tammepuu ${ }^{1,2} \&$ K. Sepp ${ }^{2}$ \\ ${ }^{1}$ Estonian Academy of Security Sciences, Estonia \\ ${ }^{2}$ Estonian University of Life Sciences, Estonia
}

\begin{abstract}
This paper presents a comparative study of the national risk assessment outcomes of two different countries of the European Union: Estonia, as a socalled 'new member' and the UK as an 'old member'. The comparative survey was carried out on the basis of the National Summary of Emergency Risk Assessments of Estonia and the National Risk Register of Civil Emergencies of the UK. The features compared were requirements, methodologies, risk assessment process and performers, risk types and categories together with risk assessment outcomes as well as output documents' composition. Simultaneously parallels were drawn with local level emergency risk assessments. Although the risk types were defined diversely in the two countries, an indirect comparison was still accomplishable. For instance, the risk of pandemic human disease was assessed as one of the highest in both countries. On the grounds of our observations, the National Risk Register of the UK was comparatively more, an advising, guiding and directing document while the Estonian emergency risk assessment summaries were in a greater part of a summarizing character.

Keywords: emergency preparedness, risk assessment, civil protection.
\end{abstract}

\section{Introduction}

The existence and survival of mankind and the whole of life in the world has been accompanied by the impacts of unexpected and hazardous events. Disasters and emergencies are samples of the destabilising factors, which can cause serious setbacks and breakdowns in the environment and society [1]. The last decades have demonstrated a significant increase of technological and natural disasters worldwide and in Europe [2]. The risks of emergencies can be out of the eye of 
public attention, as disasters are uncertain events, which happen relatively rarely. Disasters do not respect borders [3]. Therefore it is important to assess and communicate corresponding risks on local and regional as well as national and international levels.

Today risk assessment has become an essential part of civil protection and disaster management [4]. Several studies, and also comparative studies, are available concerning the integrated approach of multi-hazard territorial risk assessment and management. Lonka has conducted a comparative study of risk assessment in the field of civil protection of European countries [5]. The European research project QUARTER concentrated on the development of a territorial management system for territorial risk reduction and environmental quality improvement [6]. The report of the project EUROBALTIC I present different examples of methodologies of risk assessment, management and mapping in the Baltic Sea Region, developed and applied in the countries of the region [7]. The ESPON Hazards Project 1.3.1 has worked out spatial patterns of natural and technological hazards in Europe in the shape of an overview on all NUTS3 areas [8].

In different EU countries the usefulness of the further development of risk assessment in the field of civil protection and emergency preparedness is clearly recognized [5]. Risk assessments on a national level are recognized to be a determinant for improving disaster prevention and preparedness activities [9]. Recently the European Commission issued risk assessment guidelines with the main goals being to improve coherence among the national risk assessments and to make these risk assessments more comparable between member states $[9,10]$. Nowadays many countries are undertaking national risk assessments, including the UK $[10,11]$ and Estonia [12].

Three years earlier we carried out a comparative study of the local level emergency risk assessments of four Estonian cities (Tallinn, Tartu, Narva and Pärnu) and four cities or conurbations of the UK (London, Greater Manchester, West Midlands conurbation and Belfast) [1]. Our previous positive experience as well as the latest developments in the EU brought us to the decision to perform a comparative study of the public outcome documents of the national emergency risk assessments of the same two EU countries. Whilst Estonia is approximately 5.4 times smaller by territory and 45 times by population than the UK, the countries still have enough similar features, favouring the comparison. This comprises their relatively northern positions in Europe, a long coastal line, a low proportion of seismic and an absence of volcanic hazards, etc.

The main research materials were the latest publicly available output documents of the national risk assessments of the two countries, correspondingly: the 2008 National Summary of Risk Assessments for Emergencies [12] of Estonia and the National Risk Register of Civil Emergencies (2010 edition) [11] of the United Kingdom. The essential goal of the current study was a comparison of the publicly available outcomes and outputs of the national risk assessments of the two EU countries for bringing out and discussing the parallels and dissimilarities. The observed and compared subjects were requirements, methodologies, output documents' composition, risk 
assessment process and performers, risk types and categories as well as risk assessment outcomes. The results of the study can serve as useful information in moving towards the 2012 overview of the major risks the EU may face in the future [9].

\section{Comparison}

\subsection{General remarks}

As much as publicly available sources enable to conclude, both countries: Estonia and the UK started to organise and undertake national level risk assessments somewhere in the middle of the last decade.

In Estonia the public versions of national risk assessment summaries have been available since 2005. During that period remarkable changes have taken place, concerning the legislative requirements and methodological approaches. The currently valid Emergency Act [13] replaced the previous Emergency Preparedness Act [14], which was valid until 23 July 2009. While the previous methodology, used in the years up to 2007, was essentially based mostly on the Swedish or UNEP/APELL methodology [15], then the later methodology, used since 2008, was generically built on the example of the British methodological approach [16]. Due to this the principles and criteria of risk assessment have also remarkably transmuted during the last years. Thus the 2008 National Summary of Risk Assessments for Emergencies [12] differs considerably from the previous analogical documents.

In the UK the Government has carried out a classified assessment of the risks facing the country, since 2005 [11]. The Civil Contingencies Act 2004 [17], which is currently valid, embarked on a thorough reorganisation of the emergency management system, including risk assessment. The Government performs the National Risk Assessment (further also NRA), which is secret by nature and not directly available for public use [11, 18]. The National Risk Register (further also NRR) is a public document on the basis of National Risk Assessment and the first NRR was published in August 2008 [11, 18]. The NRR 2010 Edition, which is at the centre of attention in the current paper, is the second, updated, version, based on the 2009 iteration of the NRA [18]. The main changes to the 2010 Edition and the original NRR embrace the update of risk types and risks on the risk matrix and in the text, as well as expansions of the last chapters of advisory and informative character [18].

\subsection{Requirements and methodologies}

The Estonian Emergency Act designates risk assessment as a document which describes the following on a national and, if necessary, regional and local government level: the emergency; the threats and hazards causing the emergency; the probability of the emergency; the consequences of the emergency; other important information related to the emergency; references to models, source materials and other such information, on the basis of which the 
risk assessment is prepared. This definition emphasises clearly, that the national level approach is recognized as principal in Estonian emergency risk assessment. Emanating from the Emergency Act, the Minister of the Interior enacted an emergency risk assessment compilation guidance, which contains currently valid methodological requirements [19]. Earlier, in 2008, the more voluminous methodological guidance, approved by the Government's Crisis Management Committee was compiled (in Estonian and English) and made publicly available [20]. The 2008 National Summary of Risk Assessments for Emergencies [12] of Estonia was composed on this methodological basis.

The British Civil Contingencies Act 2004 as well as the Civil Contingencies Act 2004 (Contingency Planning) Regulations 2005 [21] principally set the risk assessment duty on Category 1 responders and Local Resilience Forums. The Category 1 responders are in brief the following institutions: emergency services, local authorities, health bodies and environment agencies [21]. This generically refers, that the essential requirements for emergency risk assessment lie on a local level. As a matter of fact the methodology of risk assessment for British local responders, brought in the emergency preparedness guidance [16] and was an essential example for working out the previously mentioned Estonian emergency risk assessment methodologies [19, 20]. The British risk assessment processes used at regional and national levels are not precisely the same as on the local level, but have many features in common and are generally consistent [16]. The laconic description of the British national risk assessment process can be recognized in the NRR edition 2010. We guess that the methodology of the British National Risk Assessment is described more thoroughly in some other document, not available for public use, as the NRA-s are mentioned to be secret and the NRR-s are only the public outputs of these [18].

\subsection{Risk assessment processes and performers}

The Estonian emergency risk assessment process, described in the methodologies $[19,20]$, generically uniform for national, regional and local levels, consists of 6 steps. The steps are almost one-for-one comparable with the steps of the British emergency risk assessment methodology for local responders, obviously for the previously described reasons and connections [16, 20]. The steps of emergency risk assessments in Estonia (national, regional, local) and in the UK (local) are presented in a comparative context in Table 1. The British national risk assessment process is described as consisting of the three main steps in the NRR 2010 edition [11], which are the following: identifying risks, assessing risks and comparison of risks. As much as the brief description of the risk assessment methodology allows proposing, the first two steps cover more or less the greater part of analogical or similar actions of the steps of the risk assessment on a local level. The third step is the comparison of risks, where priority is given to the risks that are both relatively likely and could have a serious impact, taking into account different types of planning assumptions. There is no precise analogy in Estonian national risk assessment(s), although higher risks certainly gather higher attention in emergency and spatial planning practices. 
Table 1: The steps of Estonian national [12, 20] and British local [16] emergency risk assessments.

\begin{tabular}{|c|c|c|}
\hline Step & Estonia & United Kingdom (local) \\
\hline 1 & Conceptualization & Contextualisation \\
\hline 2 & $\begin{array}{l}\text { Description of the threats and } \\
\text { consolidation for the purposes of } \\
\text { assessing the likelihood of an emergency }\end{array}$ & $\begin{array}{c}\text { Hazard review and allocation for } \\
\text { assessment }\end{array}$ \\
\hline 3 & $\begin{array}{c}\text { The assessment of possible accident's } \\
\text { probability }\end{array}$ & Risk analysis \\
\hline 4 & $\begin{array}{c}\text { Determining risk category and ranking the } \\
\text { risks }\end{array}$ & Risk evaluation \\
\hline 5 & $\begin{array}{c}\text { Preventive and alleviatory measures for } \\
\text { emergencies }\end{array}$ & Risk treatment \\
\hline 6 & $\begin{array}{l}\text { Entering results on risk form, and } \\
\text { monitoring and audit of risks }\end{array}$ & Monitoring and reviewing \\
\hline
\end{tabular}

The British NRR 2010 edition brings only relative scales for impact and likelihood assessment, on account of which these cannot be compared with the Estonian 5-point scales (basically similar with British local level).

The consequences or impacts are exemplified with four characteristics in the national risk assessments outcomes of both countries. The categories were not completely one-to-one in conformance, but were postured in a comparative context, emanating from the definitions of these characteristics $[11,12,20]$ as follows in Table 2 .

Table 2: $\quad$ The consequence (impact) categories $[11,12,20]$.

\begin{tabular}{|c|c|}
\hline Estonia & United Kingdom \\
\hline Categories of consequences & Categories of impact \\
\hline Human life and health & The number of fatalities \\
& Human illness or injury \\
\hline Vital service & Social disruption \\
\hline Natural Environment & Economic damage \\
\hline Assets & \\
\hline
\end{tabular}

The Estonian national risk assessments of different emergencies were carried out in corresponding working groups, each embracing the representatives of different bureaus and conducted by a lead ministry as was recently determined in the 2008 methodology [20]. Today the same principle is enacted by the Government of the Republic [22]. The lead ministries are shown in Table 3. Afterwards these separate assessments were collocated into a summary by the Ministry of the Interior [12]. According to the NRR 2010 edition, the British National Risk Assessment drew on expertise from a wide range of departments and agencies of government [11]. 
Table 3: $\quad$ Estonian national emergency risks $[12,20]$.

\begin{tabular}{|c|c|c|}
\hline $\begin{array}{l}\text { Number } \\
\text { (Code) }\end{array}$ & Emergency & $\begin{array}{c}\text { Lead ministry performing } \\
\text { assessment }\end{array}$ \\
\hline 1 & Extensive forest and brush fire & Ministry of the Interior \\
\hline 2 & $\begin{array}{l}\text { Extensive and/or complicated fire/explosion in } \\
\text { industrial or warehouse buildings (production } \\
\text { enterprises and warehouses with a risk of major } \\
\text { accident, including explosives depots) }\end{array}$ & Ministry of the Interior \\
\hline 3 & $\begin{array}{c}\text { Extensive and/or complicated fire/explosion as a } \\
\text { consequence of which very many people are } \\
\text { injured and must be evacuated }\end{array}$ & Ministry of the Interior \\
\hline 4 & Extensive, third-degree (oil) spill at sea & Ministry of the Interior \\
\hline 5 & (Oil) spill on coast/shore & Ministry of the Environment \\
\hline 6 & Mass unrest & Ministry of the Interior \\
\hline 7 & Mass disorder in prison & Ministry of Justice \\
\hline 8 & Road accident with many injured & $\begin{array}{l}\text { Ministry of Economic Affairs } \\
\text { and Communication }\end{array}$ \\
\hline 9 & $\begin{array}{c}\text { Accident involving passenger trains with many } \\
\text { injured }\end{array}$ & $\begin{array}{l}\text { Ministry of Economic Affairs } \\
\text { and Communication }\end{array}$ \\
\hline 10 & $\begin{array}{c}\text { Accident involving a train carrying hazmats with } \\
\text { many injured and/or major environmental } \\
\text { damage }\end{array}$ & $\begin{array}{l}\text { Ministry of Economic Affairs } \\
\text { and Communication }\end{array}$ \\
\hline 11 & $\begin{array}{l}\text { Accident involving or sinking of passenger ship } \\
\text { or ship with many casualties }\end{array}$ & $\begin{array}{l}\text { Ministry of Economic Affairs } \\
\text { and Communication }\end{array}$ \\
\hline 12 & Air accident with many casualties & $\begin{array}{l}\text { Ministry of Economic Affairs } \\
\text { and Communication }\end{array}$ \\
\hline 13 & $\begin{array}{l}\text { Emergency situation caused by biological risks } \\
\text { (including epidemic/pandemic, bioterrorism etc) }\end{array}$ & Ministry of Social Affairs \\
\hline 14 & Extraordinarily hot weather & Ministry of Social Affairs \\
\hline 15 & Extraordinarily cold weather & Ministry of Social Affairs \\
\hline 16 & $\begin{array}{c}\text { Storm } \\
\end{array}$ & Ministry of the Interior \\
\hline 17 & $\begin{array}{l}\text { Flood in a high-density area (especially } \\
\text { hazardous storm surge) }\end{array}$ & Ministry of the Interior \\
\hline 18 & Mass poisoning & Ministry of Social Affairs \\
\hline 19 & Epizootic (infectious animal disease) & Ministry of Agriculture \\
\hline 20 & Nuclear accident with cross-border impact & Ministry of the Environment \\
\hline 21 & Domestic incident involving source of radiation & Ministry of the Environment \\
\hline 22 & Extensive environmental contamination & Ministry of the Environment \\
\hline 23 & Massive immigration of refugees into the country & Ministry of Social Affairs \\
\hline 24 & Hostage crisis & Ministry of the Interior \\
\hline 25 & $\begin{array}{l}\text { Extensive financial crisis (non-functioning of } \\
\text { financial system) }\end{array}$ & Ministry of Finance \\
\hline 26 & Extensive cyber attack & Ministry of Defence \\
\hline
\end{tabular}

\subsection{Risk types and assessment outcomes}

The methodology, which was the basis of the 2008 Estonian national risk assessment, determined 26 emergency types in a one-step list, which means that the emergencies (or emergency risks) were not grouped into broader categories by certain characteristics. The types of emergencies are shown together with the ministries, responsible for performing the concrete emergency risk assessment in Table 3. The serial numbers serve simultaneously as the codes of the emergencies. 
The EU Vademecum of Civil Protection [23] generically recommends the division of the typology of emergencies into two broad categories: natural and man-made disasters. In the British NRR 2010 edition, the risks are divided into three broad categories, the first of which embraces essentially natural, and the last two man-made events. The main structure of 3 broad categories and 11 main types are shown in Table 4. The main risk types in turn contained sub-categories, which were described in the text of the NRR 2010 edition. The number of nondivided risk types and subtypes of the divided main types made altogether 23 events. These main risk types or subtypes, which are further brought out in the illustrative risk matrix (Figure 2), are marked with light-grey background.

Table 4: $\quad$ British national emergency risks [11].

\begin{tabular}{|l|c|}
\hline Risk category & Risk type \\
\hline Natural events & Human disease \\
\cline { 2 - 3 } & Pandemic human disease \\
\cline { 2 - 3 } & Non-pandemic human disease \\
\cline { 2 - 3 } & Flooding \\
\cline { 2 - 3 } & Coastal flooding \\
\cline { 2 - 3 } & Inland flooding \\
\cline { 2 - 3 } & Severe weather \\
\hline Major accidents & Animal disease \\
\cline { 2 - 3 } & Major industrial accidents \\
\hline Malicious attacks & Major transport accidents \\
\cline { 2 - 3 } & Attacks on crowded places \\
\cline { 2 - 3 } & Attacks on infrastructure \\
\cline { 2 - 2 } & Attacks on transport \\
\cline { 2 - 2 } & Non-conventional attacks \\
\cline { 2 - 2 } & Cyber attacks: infrastructure \\
\cline { 2 - 2 } & Cyber attacks: data confidentiality \\
\cline { 2 - 2 } & \\
\hline
\end{tabular}

The public output documents of the national risk assessments of both of the observed countries $[11,12]$ presented the risks on risk matrixes. The Estonian risk matrix [12] has the scale of likelihood on the vertical axis and the scale of consequences on the horizontal axis. The allocation of the scales on the British national risk register matrix [11] is the opposite. The likelihood levels on the Estonian risk matrix are marked with numbers (1-5) and the consequence levels with letters (A-E). Both scales of the British national risk register matrix reflect correspondingly relative likelihood and impact - without distributions. The Estonian national risk matrix of 2008 is shown in Figure 1 and the British national risk register matrix 2010 in Figure 2. The 26 roman numerals on Estonian matrix coincide one-to-one with the Arabic numerals in Table 3, which means that the numbers of the emergencies in the list serve simultaneously as the codes on the matrix. The British matrix presents 14 high consequence risks, 8 of which are shown as main risk types and 6 as sub-types, as displayed in Table 4. 


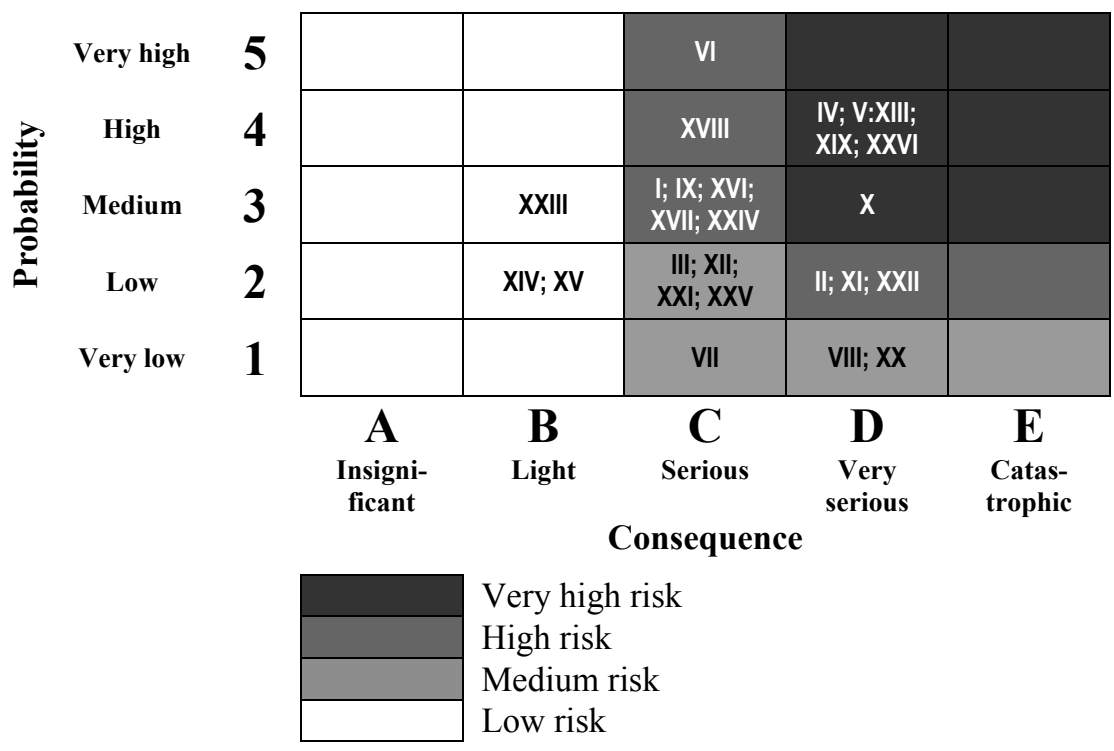

Figure 1: Estonian national risk matrix 2008 [12].

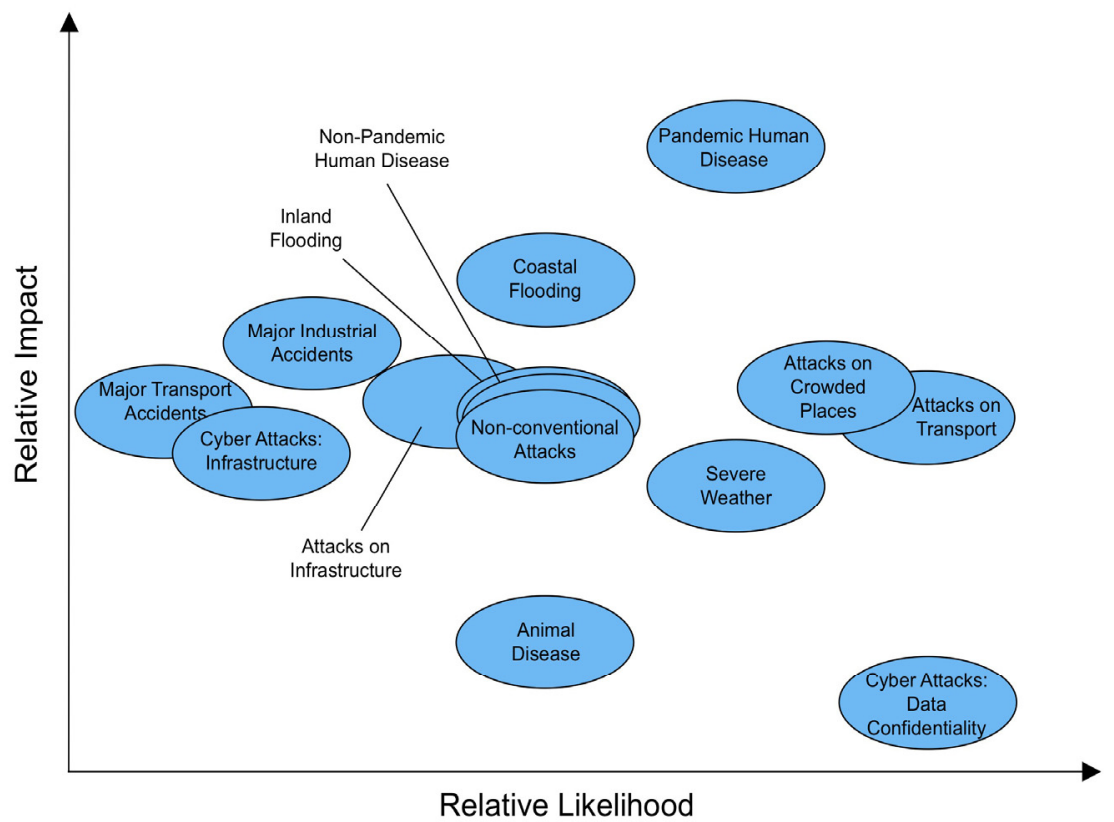

Figure 2: $\quad$ British national risk matrix 2010 [11]. 
The indirect comparison of the assessed risks of the observed countries demonstrated both: similarities and differences. The following is a set of selected examples. The risks of pandemic human disease were indicated in both countries as very high. The Estonian approach also deemed the risks of extensive oil spills as very high, but the British viewpoint did not handle these as autonomous events as these can be taken in principle as the results of industrial or transportation accidents. The risks accompanied with severe weather conditions were assessed as remarkably high in the both countries. Flood risks were also found remarkably high in the two countries, whereby in the UK coastal and inland floods were assessed separately but in Estonia the limiting criteria for flood risk assessment was localised in high-density areas. Major industrial accident risks were assessed as relatively high in the both countries, but the risks of major transport accidents were more accentuated in the Estonian approach. The assessed relative risk of cyber attacks was also observed higher in Estonia. The British NRR 2010 turned serious attention to the risks of several malicious attacks, which was even determined as one of the broad categories of risks. In the Estonian approach, these events were not handled as separate risk types, but simultaneously, for instance with the risk of mass unrest, which could bring along malicious attacks, which was assessed as high.

\subsection{Composition of the output documents}

The plain comparison of the output documents [11, 12] demonstrated remarkable differences in composition and points of view.

The 2008 National Summary of Risk Assessments for Emergencies [12] of Estonia consists of 2 generic and 26 specific Chapters and of 9 Appendixes. The specific chapters are the outputs of risk assessments of concrete emergency types. The content can be briefly displayed as follows:

- Introduction;

- Changes in comparison with the 2007 National Summary of Risk Assessments;

- Summaries of risk assessments of certain emergency types (I-XXVI);

- Appendixes (1-9).

Each specific chapter included the following sub-divisions: description of the emergency, historical facts and previous (similar) events, overview of the hazards causing the emergency, assessment of risks, existing resources and actions for emergency prevention and consequences mitigation, required additional resources and actions for emergency prevention and consequences mitigation.

Appendix 1 was a risk matrix (Figure 1), the remaining 8 appendixes contained informational materials in the forms of tables, maps or texts.

The British NRR 2010 edition consisted of the following main chapters:

1. Introduction;

2. Risks;

3. Considerations for business and organisations;

4. Preparing yourself, your family and your community for emergencies;

5. The risk assessment process. 
The Chapter 1 Introduction in the NRR 2010 edition, among other things, was partly with a summarizing character, bringing out the national risk register matrix. The Chapter 2 Risks contained a discussion of assessed risks according to the previously discussed three broad categories. For each category features were observed such as risk, background, and planning measures by the Government, the Devoted Administrations and the emergency responders. Chapters 3 and 4 contained correspondingly the considerations for businesses and recommendations for civilians. Chapter 5 was a brief overview of the risk assessment process on the national level. Each chapter contained a number of apposite Internet references.

\section{Conclusion}

The public outputs of the risk assessments of the two EU countries had both: similarities and differences. The Estonian national emergency risk assessment was based on a similar methodology as the British local emergency risk assessments since the first was worked out greatly on the basis of the second. The typologies of emergency risks of the two countries were remarkably different, but still the majority of risk types were indirectly comparable. Both countries featured risks of emergencies such as pandemic or epidemic human disease, flooding, events connected with severe weather conditions and major industrial accidents. The Estonian approach unilaterally accentuated more comparable risks such as cyber attacks, major transport accidents and (infectious) animal disease, the British on the other hand different kinds of malicious attacks. Generically the British NRR 2010 edition was a more advising, guiding and directing document while the Estonian national risk assessment output document of 2008 was in a great part a summary of different emergency risk assessments.

\section{Acknowledgements}

This research was supported by European Social Fund's Doctoral Studies and Internationalisation Programme DoRa and also by the Target Funding Project No. 1090050s07 of the Ministry of Education and Science, Estonia. The authors would like to thank Tia Ruutopõld for linguistic advice and correction.

\section{References}

[1] Tammepuu, A., Sepp, K., Paasoja, R., \& Kuusemets, V., Risk assessment of the cities of Estonia and the UK: comparative study. Sustainable City V: Urban Regeneration and Sustainability, eds. A. Gospodini, C.A. Brebbia \& E. Tiezzi, WIT Press: Southampton, UK, pp. 591-604, 2008.

[2] Carpignano, A., Golia, E., Di Mauro, C., Bouchon, S. \& Nordvik, J.-P., A methodological approach for the definition of multi-risk maps at regional 
level: first application. Journal of Risk Research, 12(3-4), pp. 513-534, 2009.

[3] Commission of the European Communities. Communication from the Commission to the European Parliament, the Council, the European Economic and Social Committee and the Committee of the Regions: A Community approach on the prevention of natural and manmade disasters. 9 p, Brussels, 23.2.2009 $\operatorname{COM}(2009) 82$ final. http://eurlex.europa.eu/ LexUriServ/LexUriServ.do?uri=CELEX:52009DC00 82:EN:NOT

[4] Tammepuu, A., Sepp, K. \& Uiga, E., Aspects of risk assessment in land use planning: the case study of Tartu. Safety and Security Engineering II. The Built Environment, eds. M. Guarascio. C.A. Brebbia \& F. Garzia, WIT Press: Southampton, UK, pp. 83-95, 2007.

[5] Lonka, H., Report on risk assessment procedures used in different European Union countries and in Norway, 39 s., Publication of the Finnish Ministry of Interior16/1999. http://europa.eu.int/comm/environment/civil/pdfdocs/ riskassfinrep.pdf

[6] Treu, M.C., Colucci \& Lodrini, S. Territorial vulnerability analysis: the methodological framework. Risk Analysis IV, ed. C. A. Brebbia, WIT Press: Southampton, UK, pp. 754-761, 2004.

[7] Hedin, S., Hellenberg, T. \& Pursiainen, C., The EUROBALTIC I (20032006) Project on Civil Protection in the Baltic Sea Region: Best Practices and Lessons Learned. Project part-financed by the European Union (European Regional Development Fund) within the BSR INTERREG III B Programme, 2006. www.helsinki.fi/aleksanteri/english/projects/files/ eurobaltic_summary_report_april_2006.pdf

[8] Schmidt-Thomé, P., Kallio, H., Jarva, J., Tarvainen, T., Greiving, S., Fleischhauer, M., Peltonen, L., Kumpulainen, S., Olfert, A., Schanze, J., Bärring, L., Persson, G., Relvão, A. M., \& Batista, M. J., The Spatial Effects and Management of Natural and Technological Hazards in Europe ESPON 1.3.1 Executive Summary. Geological Survey of Finland, 2006. www.preventionweb.net/files/3621_Finalreport.pdf

[9] EC Humanitarian Aid and Civil Protection. European Civil Protection. Risk Assessment Guidelines. http://ec.europa.eu/echo/civil_protection/civil/ prevention_risk_assessment.htm

[10] EC. Commission Staff Working Paper: Risk assessment and Mapping Guidelines for Disaster Management. Brusselsk 21, 12, 2010 SEC(2010) 1626 final, 2010. http://ec.europa.eu/echo/civil_protection/civil/pdfdocs/ prevention/COMM_PDF_SEC_2010_1626_F_staff_working_document_en .pdf

[11] Cabinet Office. National Risk Register of Civil Emergencies, 2010. http://www.cabinetoffice.gov.uk/sites/default/files/resources/nationalriskreg ister-2010.pdf

[12] Ministry of the Interior. Riiklik 2008. aasta hädaolukordade riskianalüüside kokkuvõte [The 2008 National Summary of Risk Assessments for Emergencies], 2009. www.siseministeerium.ee/public/rhorak_2008.pdf

[13] Parliament of Estonia. Emergency Act. State Gazette I, 39, 262, 2009. 
[14] Parliament of Estonia. Emergency Preparedness Act. State Gazette I, 95, 613, 2000.

[15] UNEP IE/PAC. Hazard Identification and Evaluation in a Local Community, 1992.

[16] HM Government. Emergency Preparedness - Guidance on Part I of the Civil Contingencies Act 2004, its Associated Regulations and NonStatutory Arrangements, 2005. http://interim.cabinetoffice.gov.uk/media /131903/emergprepfinal.pdf

[17] Civil Contingencies Act 2004 (c.36). The Stationery Office Limited, 2004.

[18] Cabinet Office. Summary of the Main Changes to the National Risk Register, http://interim.cabinetoffice.gov.uk/media/348989/nrr-changepaper.pdf

[19] Minister of the Interior. Hädaolukorra riskianalüüsi koostamise juhend [Instructions for Performing a Risk Analysis for an Emergency]. State Gazette I, 8, 145, 2010.

[20] Ministry of the Interior. Emergency Risk Assessment Methodology. Tallinn, 2008.

[21] The Civil Contingencies Act 2004 (Contingency Planning) Regulations 2005, Statutory Instrument 2005 No. 242, 2005. www.legislation.gov.uk/ uksi/2005/2042/contents/made

[22] Government of the Republic. Nende hädaolukordade nimekiri, mille kohta koostatakse riskianalüüs, ning hädaolukorra riskianalüüsi koostamiseks pädevate täidesaatva riigivõimu asutuste määramine [List of the Emergencies on Which Risk Assessment Is Performed and the Designation of the Executive Branch Institutions Competent to Perform Risk Assessment]. Provision of the Government of the Republic, Feb 18, 2010 No 54. www.rescue.ee/vvfiles/0/HO\%20nimekiri\%20\%20riskianalyysid.pdf

[23] EC Humanitarian Aid and Civil Protection. Vademecum - Civil Protection, 2010. http://ec.europa.eu/echo/civil_protection/civil/vademecum/menu/ 1.html 